\title{
Estimating Jury Compensation for Pain and Suffering in Product Liability Cases Involving Nonfatal Personal Injury
}

\author{
Gregory B. Rodgers*
}

\section{Introduction}

Jury awards in product liability cases are intended to compensate victims for both the economic and non-economic losses associated with their injuries. Although this goal is not controversial, the number of product liability lawsuits and the size of jury awards have become matters of increasing concern in both the legal and economic professions. ${ }^{1}$ The number of product liability cases filed in federal court increased by over $800 \%$ between 1974 and 1986, and there is substantial evidence that mean plaintiff judgments have rapidly risen over the same period (Priest, 1988).

A major focus of concern is on jury compensation for non-economic losses, usually referred to as pain and suffering. Compensation for pain and suffering accounts for a substantial proportion of jury awards, but is the least well defined and most variable component of awards. Nor is there a well specified definition of what pain and suffering is or how it should be measured (Bovbjerg, Sloan and Blumstein, 1989; Viscusi, 1988). Attorneys therefore call for a variety of subjective methods to be used by juries to compensate plaintiffs for pain and suffering; juries, in turn, have wide discretion but little guidance in their decisions.

Jury awards for pain and suffering consequently vary widely on a caseby-case basis, and are generally viewed as subjective and highly unpredictable. Widely varying awards reduce the fairness of the tort system by treating similar injuries differently. Varying and unpredictable awards may also undercut the deterrence function of the law by sending confusing signals to defendants (Bovbjerg et al., 1989). Such awards may even tend to discourage innovation and the development and manufacture of valuable products (Litan, 1991).

These problems have led reform advocates to make a number of recommendations. One option is to limit compensation for pain and suffering, as a number of states have already done. However, caps on awards are likely to be discriminatory because they tend to penalize younger, more severely injured persons who often receive little compensation from other sources (Danzon, 1988; Viscusi, 1991).

Another option is to develop descriptive "schedules" or "guidelines" to provide rational standards for pain and suffering awards, much as sentencing guidelines have been established in some states in criminal proceedings.

\footnotetext{
*Senıor economist at the U.S. Consumer Product Safety Commission. The views expressed are those of the author and are not intended to represent the views of the Commission or other members of its staff.

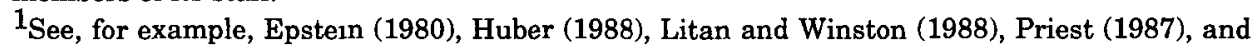
Viscusi (1991).
} 
Bovbjerg et al. (1989), for example, propose a generally fixed schedule in which pain and suffering awards are determined by the severity of the injury and the age of the injured person; dollar levels for the schedules would be based on a statistical analysis of past jury awards. Along the same lines, Levin (1989) recommends the development of guidelines to be used as a flexible tool by juries for determining pain and suffering awards. Such guidelines would model existing practices to the extent possible, but would also allow juries some discretion in award amounts.

The premise behind these scheduling approaches is that juries on average respond systematically to evidence of plaintiffs' injuries. In other words, despite variation in individual cases, jury compensation for pain and suffering is not entirely random. Viscusi (1988) provided preliminary evidence supporting this contention. He evaluated a database of over 10,000 closed product liability claims and found that payments for pain and suffering varied systematically with the economic losses associated with injuries, the character of injuries, and the liability doctrine involved in claims. However, the closed claim database consisted mostly of out-of-court settlements; successful court verdicts for plaintiffs were rendered in only about $1.5 \%$ of the total. ${ }^{2}$ Because of the small sample of jury awards, Viscusi (1988) did not present a statistical analysis of jury compensation for pain and suffering.

The purpose of this article is to quantify the factors associated with jury compensation for pain and suffering in product liability cases involving nonfatal personal injury. The analysis is based on jury award data from Jury Verdict Research, Inc. (JVR), and shows that compensation for pain and suffering varies greatly on a case-by-case basis but is by no means random. Pain and suffering awards are systematically related to economic losses and to the type and severity of injury. This does not mean that current levels of compensation for pain and suffering in jury verdicts are appropriate: such a judgment depends upon the goals of compensation. However, the results do suggest that it is feasible to develop the guidelines or schedules described earlier.

The model used to estimate pain and suffering is presented in Section II. Section III describes the data sample. Section IV presents the statistical analysis, and Section V discusses the results.

\section{The Model}

Jury awards for compensatory damages are intended to give injured parties a sum of money which will restore them, as nearly as possible, to the position they would have been in if the wrong had not been committed. ${ }^{3}$ Jury awards consist of two general components: compensation for economic losses and compensation for the non-economic losses associated with pain and suffering. ${ }^{4}$ Economic losses, often referred to as monetary losses, include

\footnotetext{
${ }^{2}$ As pointed out by Viscusi (1988, p. 214), "Out-of-court settlements understate the actual role of pain and suffering to the extent that the various aspects of the litigation process lower the plaintiffs reservation price and the insurance company's maximum offer amount below the expected court award. Chief among these dampening influences are the chances that the plaintiff could lose in court, litigation costs, and plaintiff risk aversion."

${ }^{3}$ Punitive damages, which are intended to punish negligent defendants and to deter others from causing similar accidents, are not considered in this analysis, nor are they provided in the JVR data.

${ }^{4}$ According to American Jurisprudence 2d (1988, p 130), "Damages in personal injury cases
} 
medical expenses, wage loss, and other out-of-pocket expenses. Pain and suffering is generally a catchall for all non-economic (i.e., nonmonetary) damages to the person (or persons) suffering injury, and awards for pain and suffering are generally viewed as the non-negative residual difference between jury awards and the compensation for economic losses.

To develop a model to estimate pain and suffering, assume that each plaintiff who wins a product liability case has the potential to receive a jury award for compensatory damages which is greater than the economic losses sustained in the injury. Let the total award potential, denoted by $\mathrm{A}_{1}^{*}$ for the i-th plaintiff, be estimated as

$$
A_{1}^{*}=\beta_{0}+\beta_{1} E_{1}+\beta_{2} X_{1}+\varepsilon_{1}^{*}
$$

where $\mathrm{EL}_{1}$ is the economic loss associated with injury, $\mathrm{X}_{1}$ is a vector of other independent variables associated with the jury award, $\beta$ is a vector of coefficients, and $\varepsilon_{1}^{*}$ is a normally distributed error term.

In addition, define

$$
\mathrm{A}_{1}^{*}=\mathrm{EL}_{\mathrm{i}}+\mathrm{PS}_{1}^{*}
$$

where $\mathrm{PS}_{\mathrm{i}}{ }^{*}$ represents the potential jury compensation for pain and suffering.

To solve for $\mathrm{PS}_{1}{ }^{*}$, the variable of interest, substitute equation 2) into equation 1), such that

$$
\mathrm{EL}_{\mathrm{i}}+\mathrm{PS}_{1}^{*}=\beta_{0}+\beta_{1} \mathrm{EL}_{\mathrm{i}}+\beta_{2} \mathrm{X}_{\mathrm{i}}+\varepsilon_{\mathrm{i}}^{*}
$$

Solving for $\mathrm{PS}_{1}^{*}$, we have

$$
\begin{aligned}
\mathrm{PS}_{1}^{*}= & \beta_{0}+\left(\beta_{1}-1\right) \mathrm{EL}_{1}+\beta_{2} \mathrm{X}_{\mathrm{i}}+\varepsilon_{1}^{*}, \\
= & \beta_{0}+\beta_{1}{ }^{\prime} \mathrm{EL} \mathrm{L}_{\mathrm{i}}+\beta_{2} \mathrm{X}_{\mathrm{i}}+\varepsilon_{\mathrm{i}}^{*}, \\
& \text { where } \beta_{1}{ }^{*}=\beta_{1}-1 .
\end{aligned}
$$

Not all successful plaintiffs, however, receive jury compensation for pain and suffering. $\mathrm{PS}_{1}{ }^{*}$ can therefore be characterized as a "latent" variable, equaling the actual compensation for those plaintiffs who receive awards for pain and suffering, and the potential compensation for those who do not. For plaintiffs who do not receive compensation for pain and suffering, however, the observed value of the compensation, denoted by $\mathrm{PS}_{1}$, is recorded as zero. Thus, instead of observing $\mathrm{PS}_{1}{ }^{*}$ we observe $\mathrm{PS}_{1}$, which is defined as

$$
\begin{aligned}
\mathrm{PS}_{1} & =\mathrm{PS}_{1}^{*} \text { if } \mathrm{PS}_{1}^{*}>0, \\
& =0 \text { if } \mathrm{PS}_{1}^{*} \leq 0 .
\end{aligned}
$$

The actual estimated equation then appears as

$$
\mathrm{PS}_{1}=\beta_{0}+\beta_{1}^{\prime} \mathrm{EL}_{\mathrm{i}}+\beta_{2} \mathrm{X}_{1}+\varepsilon_{\mathrm{i}}
$$

where $\mathrm{PS}_{1}$ is truncated at zero and $\varepsilon_{1}$ is truncated at $-\left(\beta_{0}+\beta_{1}{ }^{\prime} \mathrm{EL}_{\mathrm{i}}+\beta_{2} \mathrm{X}_{1}\right)$. suffering. .". 
Since the observed distribution of compensatory awards for pain and suffering is censored (i.e. only non-negative awards are observed), equation 6) cannot be estimated consistently with an ordinary least squares regression model. It can, however, be estimated with a Tobit model, a maximum likelihood estimator that provides consistent estimates of the parameter vector $\beta$ (Maddala, 1983).

\section{Data Sources and Awards for Pain and Suffering}

The analysis is based on jury awards for compensatory damages in 859 product liability cases involving nonfatal personal injury. The jury awards were made between the years 1974 and 1986 . They were published by JVR during the 1985-1987 time period, and coded by A.D. Little, Inc. (1988). JVR is a private company that collects information on civil court-awarded damages in a large proportion of all personal injury cases tried in the United States. The data exclude out-of-court settlements, cases that were dismissed, and cases in which zero compensatory damages were awarded. The data from JVR are not a random sample of court awards, but they are intended to be broadly representative of awards for various types of injuries from across the nation.

JVR provides information on a number of variables describing injuries and awards. Data include jury awards for compensatory damages to plaintiffs for damages incurred prior to verdict. Medical expenses and lost wages, the major direct economic costs of injury, are aggregated in a category called specials. The JVR data also contain information on the age and gender of the plaintiff, the body part injured, the type of injury (i.e., diagnosis), and the year of verdict.

JVR does not explicitly provide information on the pain and suffering component of jury awards. Nor do most states delineate the compensation for pain and suffering from other components of jury awards. However, as in Viscusi (1988), jury awards for pain and suffering for the i-th plaintiff (PS $)$ can be defined as the non-negative difference between actual jury awards $\left(A_{i}\right)$ and the economic losses $\left(E L_{1}\right)$ sustained by the plaintiff. ${ }^{5}$ That is,

$$
\begin{aligned}
\mathrm{PS}_{1} & =\mathrm{A}_{1}-\mathrm{EL}_{1} \text {, when } \mathrm{A}_{\mathrm{i}}>\mathrm{EL}_{1}, \\
& =0 \text {, otherwise }
\end{aligned}
$$

Economic losses consist primarily of medical costs and lost wages, designated as specials by JVR, but they also include some other out-of-pocket expenses (i.e., other economic losses). Although estimates of these other economic losses are not available from JVR, information from the Insurance Services Office Closed Claim Survey (1977) indicate that other economic losses averaged only about $5.5 \%$ of total economic losses. For purposes of this analysis, economic losses from the JVR database will therefore be assumed to be given by $\mathrm{EL}_{1}=\left(\mathrm{SP}_{1} \div .945\right)$, where $\mathrm{SP}_{1}$ represents specials.

The above imputation for pain and suffering is not intended as an exact measure. Nevertheless, it provides an approximate measure of pain and suffering that is instructive in determining whether or not juries systematically value pain and suffering and, if so, the factors that contribute to compensation for pain and suffering.

${ }^{5}$ Danzon (1985) also took this approach in estimating the pain and suffering awards in medical malpractice suits. 
Table 1 summarizes the characteristics of the cases and plaintiffs, including the age and gender of plaintiffs, the type of injury, the body part affected, and whether the injury involved hospitalization. ${ }^{6}$ The 859 cases cover a wide range of injuries and involve victims whose ages range from 3 to 83. About two-thirds of the cases came to verdict in the period of 1982 through 1984.

Table 1

Sample Characteristics

$$
\begin{aligned}
& \text { Variable } \\
& \text { Age }(n=664) \\
& \text { Male }(n=787) \\
& \text { Hosp. }(n=859) \\
& \text { Year }(n=859)
\end{aligned}
$$

Body Part Injured

Head

Face

Ear/Mouth

Eyeball

Neck

UpperTrunk

Shoulder

Arm

Hand/Wrist

LowerTrunk

Leg/Knee

Foot/Ankle

Total

Diagnosis

Amputation

Burns

Concussion

Contusion

Dental

Dislocation

Fracture

Hematoma

Laceration

NerveDamage

Sprain

Other

Total
Mean Std. Dev.

36.22

.57

.42

1981.86

19.14

.49

.49

2.13

$\begin{array}{rr}\mathrm{n} & \% \\ 38 & 4.4 \\ 51 & 5.9 \\ 29 & 3.4 \\ 31 & 3.6 \\ 47 & 5.5 \\ 136 & 15.8 \\ 20 & 2.3 \\ 51 & 5.9 \\ 26 & 3.0 \\ 135 & 15.7 \\ 169 & 19.7 \\ 125 & 14.7 \\ & \\ 859 & 100.0\end{array}$

$\begin{array}{rr}\mathbf{n} & \% \\ 26 & 3.0 \\ 32 & 3.7 \\ 17 & 2.0 \\ 35 & 4.1 \\ 18 & 2.1 \\ 15 & 1.7 \\ 394 & 45.9 \\ 10 & 1.2 \\ 60 & 7.0 \\ 58 & 6.8 \\ 181 & 21.1 \\ 13 & 1.5 \\ & \\ 859 & 100.0\end{array}$

${ }^{6}$ The JVR data do not specify inpatient hospital treatment. A.D. Little coded injuries as resulting in hospitalization "only when the type of injury clearly indicated [hospitalization] to be the case" (A.D. Little, 1988, p. 10). 
Table 2 presents information on mean pain and suffering awards for various levels of economic losses, in 1988 dollars. The wide variation in the pain and suffering awards is notable: the standard deviations are greater than the mean levels and reflect the case-specific valuations made by juries. Cases with economic losses of less than $\$ 10,000$ predominate, with about $60 \%$ of the total; $23 \%$ of the cases involved losses of under $\$ 2,000$. For the sample, losses average about $\$ 18,000$ and compensation for pain and suffering averages about $\$ 66,000$.

Table 2

Pain and Suffering, by Level of Economic Losses

$\begin{array}{ccccc}\begin{array}{c}\text { Range for } \\ \text { Economic } \\ \text { Losses }\end{array} & \begin{array}{c}\text { Mean } \\ \text { Economic } \\ \text { Loss }\end{array} & \begin{array}{c}\text { Mean } \\ \text { Pain and } \\ \text { Suffering }\end{array} & \begin{array}{c}\text { \% of Awards } \\ \text { for Pain and } \\ \text { Suffering }\end{array} & \mathrm{N} \\ \begin{array}{c}\$ 2,000 \\ \text { or less }\end{array} & \$ 993 & \begin{array}{c}\$ 8,918 \\ (16,279)\end{array} & 90.0 & 197 \\ \begin{array}{c}\$ 2,001 \text { to } \\ 10,000\end{array} & \begin{array}{l}\$ 5,312 \\ (2,232)\end{array} & \begin{array}{c}\$ 32,302 \\ (72,218)\end{array} & 85.9 & 313 \\ \begin{array}{c}\$ 10,001 \text { to } \\ 25,000\end{array} & \begin{array}{l}\$ 16,737 \\ (4,372)\end{array} & \begin{array}{c}\$ 70,552 \\ (100,700)\end{array} & 80.8 & 178 \\ \begin{array}{c}\$ 25,001 \text { to } \\ 50,000\end{array} & \begin{array}{c}\$ 34,824 \\ (7,084)\end{array} & \begin{array}{c}\$ 146,360 \\ (176,920)\end{array} & 80.8 & 85 \\ \$ 50,001 \text { or } & \$ 102,750 & \$ 270,050 & 72.4 & 70 \\ \text { more } & (54,920) & (290,960) & & \\ \text { Total } & \$ 17,782 & \$ 66,157 & 78.8 & 843 \\ & (31,806) & (139,600) & & \end{array}$

Note: Standard deviations are in parentheses. Reported figures are in 1988 dollars.

Not surprisingly, the Table 2 results indicate that pain and suffering awards increase with economic losses. This is probably because injuries with greater losses tend to be more severe. For example, all else equal, a fracture of the leg with economic losses of $\$ 2,000$ is likely to be more severe than a fracture with losses of $\$ 500$. While the pain and suffering awards increase with economic losses, it also appears from Table 2 that they increase at a decreasing rate. This relationship is consistent with other jury award data in product liability cases (Landes, 1982; Viscusi, 1986), and in medical malpractice suits (Danzon and Lillard, 1983).

Injury type may provide another measure of severity since certain types of injuries lead to greater levels of physical and emotional trauma (or mental anguish) than others. A crushing of the chest, for example, is more lifethreatening than a crushing of the leg. A burn covering a large part of the body may be more painful than a fracture of the leg. Similarly, a burn to the head may be more disfiguring than an abrasion to the head. 
Accordingly, injuries reported in the JVR data have been assigned to four injury severity categories on the basis of the injury diagnosis and body part affected. The injury categories, which are exemplified in Table 3 , are based on an ordinal severity classification of injuries developed by the National Commission on Product Safety (1970) in an informal (and interdisciplinary) attempt to combine injuries of approximately similar severity for the subsequent analysis of product hazards. They are numbered in a presumed ascending order of severity; Category-1 injury types are least severe and Category-4 injury types are most severe.

Table 3

Injury Category Classification for Selected Injuries
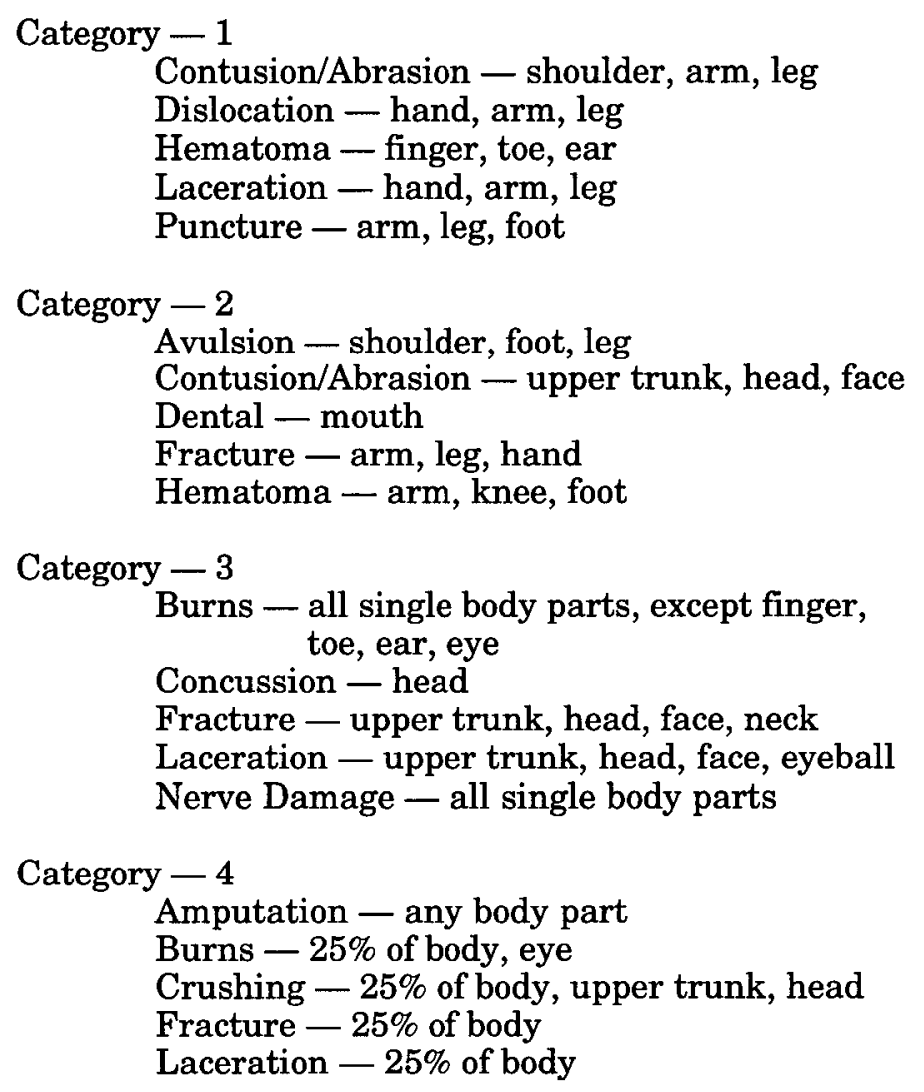

Table 4 presents mean estimates of pain and suffering awards and economic losses, by injury category. Although there is considerable variation within the various injury categories, pain and suffering awards are greater in the higher injury categories, as would be expected if the injury classification does is in fact reflect injury severity. 
Table 4

Pain and Suffering, by Injury Category

$\begin{array}{ccccc}\begin{array}{c}\text { Range for } \\ \text { Economic } \\ \text { Losses }\end{array} & \begin{array}{c}\text { Mean } \\ \text { Economic } \\ \text { Loss }\end{array} & \begin{array}{c}\text { Mean } \\ \text { Pain and } \\ \text { Suffering }\end{array} & \begin{array}{c}\text { \% of Awards } \\ \text { for Pain and } \\ \text { Suffering }\end{array} & \mathrm{N} \\ \text { Category 1 } & \begin{array}{c}\$ 7,048 \\ (10,902)\end{array} & \begin{array}{c}\$ 35,678 \\ (97,140)\end{array} & 83.5 & 139 \\ \text { Category 2 } & \begin{array}{c}\$ 17,709 \\ (31,574)\end{array} & \begin{array}{c}\$ 49,888 \\ (109,390)\end{array} & 73.8 & 362 \\ & & & & \\ \text { Category 3 } & \$ 20,747 & \$ 76,939 & 78.8 & 315 \\ & (33,779) & (142,410) & & \\ \text { Category 4 } & \$ 39,437 & \$ 315,410 & 88.9 & 27 \\ & (57,444) & (308,840) & & \\ \text { Total } & \$ 17,782 & \$ 66,157 & 78.8 & 843\end{array}$

Note: Standard deviations are in parentheses. Reported figures are in 1988 dollars.

\section{Statistical Analysis}

\section{A. Model Specification}

The independent variables of the pain and suffering regression model include several possible measures of injury severity. As mentioned above, economic losses (EL) are one possible measure. More serious injuries are probably associated with higher levels of economic losses and, presumably, greater pain and suffering. The medical expenses component of economic losses may represent the extent and/or duration of medical care, and the lost wages component provides a measure of the time required for convalescence.

Injuries requiring hospitalization are presumably more severe than injuries not requiring hospitalization. This effect is picked up by HOSP, a dummy variable that takes on a value of one if the injury required hospitalization. In addition, injury type, as measured by dummy variables representing the various injury categories (CAT-1 to CAT-4), may provide a direct measure of the relative severity of injuries. If the injury classification scheme described above provides an ascending measure of injury severity, we would expect pain and suffering awards to be higher for injuries in the higher injury category classifications.

The model also includes several variables representing the personal characteristics of plaintiffs. The possible impact of age on pain and suffering compensation is captured by a continuous AGE variable, or, alternatively, by a dummy variable set equal to one for plaintiffs under age 18 (CHILD). The gender of the plaintiff is represented by MALE, a dummy variable set equal to one if the plaintiff was male. Finally, since the JVR 
data include verdicts awarded from 1974 through 1986, a time variable (TREND) is included to pick up any component of the pain and suffering awards that are associated with time.

\section{B. Regression Results}

The regression results are presented in Table 5. Both the dependent variable, PS, and EL were entered into the equations as natural logarithms. ${ }^{7}$ This transformation better captures the nonlinear relationship between PS and EL, and also reduces the distorting effects of outliers on the results.

Table 5

Tobit Regression Results, Awards for Pain and Suffering ${ }^{a}$

\begin{tabular}{|c|c|c|c|c|c|c|}
\hline \multirow[b]{2}{*}{ Variables $^{b}$} & \multicolumn{2}{|c|}{ Model 1} & \multicolumn{2}{|c|}{ Model 2} & \multicolumn{2}{|c|}{ Model 3} \\
\hline & Coeff. & T-Ratio & Coeff. & T-Ratio & Coeff. & T-Ratio \\
\hline Constant ${ }^{*}$ & 7.572 & 6.02 & 7.015 & 5.61 & 7.203 & 6.61 \\
\hline $\mathrm{EL}^{*}$ & .385 & 4.24 & .403 & 4.47 & .374 & 4.89 \\
\hline HOSP* & 1.024 & 3.55 & .951 & 3.31 & .988 & 3.97 \\
\hline CAT-2 & .391 & 1.18 & .430 & 1.31 & .420 & 1.50 \\
\hline CAT- ${ }^{*}$ & .898 & 2.59 & .976 & 2.84 & .957 & 3.25 \\
\hline CAT-4* & 2.818 & 4.21 & 2.818 & 4.23 & 2.715 & 4.54 \\
\hline MALE & -.348 & -1.54 & -.356 & -1.60 & - & - \\
\hline AGE & -.005 & -.84 & 一 & - & - & - \\
\hline CHILD* & - & - & .892 & 2.70 & - & - \\
\hline TREND* & -.734 & -2.71 & -.720 & -2.67 & -.697 & -2.87 \\
\hline TRENDSQ ${ }^{*}$ & .050 & 2.84 & .049 & 2.83 & .046 & 2.94 \\
\hline Observations & 62 & & 6 & & & \\
\hline Limit Obs. & 3 & & 3 & & & \\
\hline Non-Limit Obs & bs. $\quad 5 \varepsilon$ & & 5 & & & \\
\hline Log-Likelihood & $-1,47$ & .07 & $-1,47$ & 2.76 & $-2,0$ & 2.14 \\
\hline Std. Err. of Est. & $2 .^{\prime}$ & & 2 & & & \\
\hline
\end{tabular}

${ }^{*}$ Significant in each regression at $p<0.05$, two-tailed test.

aThe dependent variable is the natural logarithm of $\left(\mathrm{PS}_{\mathrm{i}}+1\right)$

bIndependent Variables:

$\mathrm{EL} \quad=$ the natural logarithm of economic losses;

HOSP $=1$ if the plaintiff was hospitalized, 0 otherwise;

CAT- $i=1$ if the injury category is Category- $i, 0$ otherwise;

MALE $=1$ if the plaintiff was a male, 0 if female;

AGE $\quad=$ the age of the plaintiff;

CHILD $\quad=1$ if the plaintiff was less than 18 years-of-age, 0 otherwise;

TREND = year-1973 (1974 was the year of the earliest award);

TRENDSQ $=$ the square of TREND.

${ }^{7}$ Since the natural $\log$ of zero is undefined, the dependent variable was defined as $\ln \left(\mathrm{PS}_{\mathrm{i}}+1\right)$. 
Several specifications of the model are estimated. Model 1 includes the personal characteristic variables, AGE and MALE; the variable CHILD is substituted for AGE in Model 2. In addition, Model 3 is estimated without the age and gender variables, which were frequently unknown.

All of the equations are significant, and the estimated models are quite consistent with one another. The missing data in the first two models do not appear to have substantially altered the statistical results.

Estimated compensation for pain and suffering increases with economic losses. Because the dependent variable, PS, and EL were expressed as natural logarithms, the coefficients for EL (which range from 0.37-0.40 in the three models) represent the elasticities of the pain and suffering awards with respect to changes in economic losses. Thus, pain and suffering awards increase with losses, as expected, but with elasticities that are less than unity. ${ }^{8}$ It is not clear why cases with higher levels of economic losses are compensated proportionately less than cases with smaller economic losses, but Viscusi (1988) speculates that the elasticity may be influenced by biases in reporting economic losses: plaintiffs may tend to overestimate losses. Alternatively, juries may simply believe that compensatory damages for pain and suffering should not increase proportionately to economic losses.

Hospitalization results in a substantial increase in the compensation for pain and suffering. The coefficients indicate that hospitalization increases compensation for pain and suffering by roughly $170 \%$ when compared to injuries that did not result in hospitalization. ${ }^{9}$

The injury type dummy variables are significant as a group, based on a likelihood ratio test. The models exclude the CAT-1 dummy variable from the estimating equations to prevent singularities; the coefficients for the CAT-2, CAT-3, and CAT-4 variables therefore represent the effects of these injury classifications on pain and suffering awards, relative to CAT-1 injury types. Although the coefficients for the CAT-2 injury types are not significant in any of the models, taken at face value they suggest that CAT-2 injuries result in pain and suffering awards that are roughly 50\% higher than CAT-1 injuries. Similarly, CAT-3 and CAT-4 injuries result in pain and suffering awards that are roughly $160 \%$ and $1400 \%$ higher than CAT-1 injuries, respectively.

The coefficients for the age and gender variables in Model 1 are not significant at the usual 5\% significance level. However, the coefficient for CHILD in Model 2 is significant, and may suggest that juries increase awards when children are involved. Specials for children averaged only about half the level of specials for adults, probably because of lower wage losses. The results may therefore suggest that juries tend to discount the effects of lower specials for children in making awards for pain and suffering. The results may also reflect the potentially longer duration of the pain and suffering losses for children in the case of permanent injuries.

Time was entered into the models as a quadratic variable, and both terms (TREND and TRENDSQ) are significant. The coefficients for these two terms imply that the awards for pain and suffering were minimized,

\footnotetext{
${ }^{8}$ This lack of a proportional increase in pain and suffering compensation is not simply the result of the variables other than EL picking up some of the compensation effects. Exclusion of all variables other than EL raises the elasticity to only 0.61 .

${ }^{9}$ Since the equation is estimated in log form, the percentage impact of the categorical HOSP variable on PS is equal to: exp(coeff.) - 1. In Model 3, for example, the percentage increase in pain and suffering compensation associated with hospitalization is, $\exp (0.988)-1=1.68$.
} 
with respect to time, in about 1980 . This is consistent with data on medical malpractice insurance rates, which declined in the late 1970 s only to climb again in the early 1980s (Danzon, 1988; Schiffman, 1989).

\section{Discussion}

The results of the models are generally as expected: higher pain and suffering awards are associated with more severe injuries, as measured by economic losses, hospitalization, and injury type. So while pain and suffering awards are subject to considerable variation, they are nonetheless a function of variables that we can specify. This suggests that descriptive schedules or guidelines for pain and suffering, of the type advocated by Bovbjerg et al. (1989) and Levin (1989), can be developed.

However, it should be noted that such schedules are not likely to reduce overall liability costs substantially, a major goal of current proposals to cap awards. ${ }^{10}$ Although schedules may help control the rate of growth in pain and suffering awards over time, compensation levels based on descriptive schedules would, by definition, be on a par with current levels. Their main effect would be to increase the uniformity of tort awards and increase the efficiency of the tort system, not to reduce liability costs.

Moreover, the demonstration of systematic variation in compensation for pain and suffering does not imply that current levels are appropriate. As Viscusi (1988, p.218) points out, "Pain and suffering schedules would constitute a form of financial discipline, but until a procedure is developed to establish a sound basis for setting pain and suffering amounts there will be no compelling justification for any specific schedule." Establishing a sound basis for compensation levels may be especially important since, as shown by Calfee and Winston (1988), the presence of non-economic losses creates a conflict between the insurance and injury deterrence functions of tort law, the two main economic rationales for tort compensation.

\section{References}

Bovbjerg, Randall, R., Sloan, Frank A., and Blumstein, James F.,"Valuing Life and Limb in Tort: Scheduling Pain and Suffering," Northwestern Law Review, Summer 1989, 83(4), 908-76.

Calfee, John E., and Winston, Clifford, "Economic Aspects of Liability Rules and Liability Insurance," in Robert E. Litan and Clifford Winston, eds., Liability: Perspectives and Policy, Washington, DC: Brookings, 1988.

Danzon, Patricia M., "Florida Malpractice Awards for Pain and Suffering," in Medical Malpractice Policy Guidebook, Henry G. Manne, ed., Jacksonville FL: Florida Medical Association, 1985.

"Medical Malpractice Liability," in Robert E. Litan and Clifford Winston, eds., Liability: Perspectives and Policy, Washington, DC: Brookings, 1988.

, and Lillard, Lee A., "Settlement Out of Court: The Disposition of Medical Malpractice Claims," Journal of Legal Studies, 1983, 12, 34575 .

${ }^{10}$ However, Bovbjerg et al. (1989) point out that the tort system is expensive to run and suggest that increased standardization of pain and suffering compensation may reduce administrative costs by improving the efficiency of the system. 
Epstein, Richard E., Modern Products Liability Law: A Legal Revolution, Westport, CN: Quorum Books, 1980.

Huber, Peter W., Liability: The Legal Revolution and Its Consequences, New York, NY: Basic Books, 1988.

Landes, Elizabeth M., "Compensation for Automobile Accident Injuries: Is the Tort System Fair?," Journal of Legal Studies, 1982, 11, 253-259.

Levin, Frederick S., "Pain and Suffering Guidelines: A Cure for Damages Measurement Anomie," Journal of Law Reform, Winter 1989, 22(2), 303-32.

Litan, Robert E., and Winston, Clifford, eds., Liability: Perspectives and Policy, Washington, DC: Brookings, 1988.

Litan, Robert E., "The Safety and Innovation Effects of U.S. Liability Law: The Evidence," American Economic Review, May 1991, 81(2), 59-64.

Maddala, G.S., Limited-Dependent and Qualitative Variables in Econometrics, Cambridge, MA: Cambridge University Press, 1983.

Priest, George L., "The Current Insurance Crisis and Modern Tort Law," The Yale Law Journal, June 1987, 96(7), 1521-1590.

"Products Liability Law and the Accident Rate," in Liability: Perspectives and Policy, Washington, DC: Brookings, 1988.

Schiffman, J.R., "Medical-Malpractice Insurance Rates Fall," Wall Street Journal, 28 April 1989, Sec. B, p. 1.

Viscusi, W. Kip, "The Determinants of the Disposition of Product Liability Claims and Compensation for Bodily Injury." Journal of Legal Studies, June 1986, 15, 321-46.

"Pain and Suffering in Product Liability Cases: Systematic Compensation or Capricious Awards?," International Review of Law and Economics, 1988, 8, 203-20. , Reforming Products Liability, Cambridge, MA: Harvard University Press, 1991.

A.D. Little, Inc., "Updating the Injury Cost Model: Estimates of Pain and Suffering," Contract CPSC-C-1987, Cambridge, MA: Author, 1988.

American Jurisprudence 2d., Damages, Vol. 22. edited by D.P. Van Knapp, Rochester, NY: Lawyers Co-operative Publishing Co., 1988.

Insurance Services Office, Product Liability Closed Claim Survey: A Technical Analysis of Survey Results, New York, NY: Author, 1977.

Jury Verdict Research, Inc., Personal Injury Valuation Handbooks, Solon, OH: Author, various issues 1985-87.

National Commission on Product Safety, "Generation of Frequency-Severity Index," in Product and Injury Identification: Supplemental Studies, Washington, DC: Government Printing Office, 1970. 